UDC 579

DOI: 10.15587/2519-8025.2017.118191

\title{
THE EFFECT OF MICROELEMENTS ON THE ACTIVITIES OF PEROXIDASE AND POLYPHENOLOXIDASE IN EGGPLANT LIEAVES AND FRUIT
}

\author{
(C) N. Mangaladze
}

Був вивчений вплив мікроелементів (B, Zn, Cu, Co, Mn)на активність пероксидази та поліфенолоксідази в листі та плодах баклажану. Об'єктом дослідження був сорт баклажанів “Dark” (solanum melongela L.), поширений в наших умовах. Перед засіванням насіння баклажану було оброблене $0.02 \%$ - розчином $\mathrm{ZnSO}_{4} . \mathrm{CuSO}_{4}, \mathrm{CoCl}_{2}, \mathrm{KMnO}_{4}, \mathrm{H}_{3} \mathrm{BO}_{3}$. Контрольне насіння було оброблене дистильованою водою. Після просушки насіння було посіяно на експериментальній ділянці. Активність досліджуваних ферментів змінюється в різних фазах росту рослини

Ключові слова: баклажан, пероксідаза, поліфенолоксідаза, мікроелементи, кобальт, ичнк, бор, фермент, активність

\section{Introduction}

Microelements are necessary for normal processes of metabolism in the living bodies. They are related to vitamins, hormones, enzymes, therefore, play a significant role in growth and development of the body [1].

The source of microelements is the soil with the chemical elements of mother rock as well as the gases, meteorite showers, smoke, volcanoes. Microelements occur in the solid particles of the soil and in the surface colloids. Microelements content in soil is dynamic in vegetation periods, for example, manganese, copper and iron content is in the greatest amount in spring, when there is great amount of moisture and the anaerobic processes are going on. In early spring these elements are less absorbable for plants. Microelements content in different types of soil is different, for example, zinc accumulates in meadow and reeded podzolic soils, while they are in the least amount in dark podzolic soils; copper accumulates in irrigated and reeded soils, cobalt content does not differ according to the soil types. The content of manganese and molybdenum is reduced in the deeper layers of soil.

Microelements introduced to plants through fertilizers stimulate their growth and development, and increase the crop. However microelements have different action on different effect on one and the same plant in different phases of vegetation. Therefore, is it necessary to estimate the exact doses of microelements according to the soil type [2].

Microelements in plant should not exceed a certain control point, for example, $\mathrm{Mn}-40.0$, Mo - 0.20, $\mathrm{Co}-1.5, \mathrm{Zn}-0.3, \mathrm{~B}-0.5 \mathrm{mg} / \mathrm{kg}[2]$. They can be delivered to plants in three ways:

1) By means of roots through introduction of microelements into soil;

2) By means of spraying the leaves weak solution;

3) By means of pre-sowing treatment of a seed in aqueous solution of salt of microelements.

Pre-sowing treatment is more effective for studying the effect of microelements, because in such a case seeds can absorb maximum amount of microelements, the embryo begins development earlier and the microelements' influence spreads on the new cells generated by the embryo division [3].
There was Studied the effect of microelements (B, $\mathrm{Zn}, \mathrm{Cu}, \mathrm{Co}, \mathrm{Mn}$ ) on the activity of the enzymes - peroxidase and polyphenol oxidase in eggplant leaves and fruit. Peroxidase (EC1.11.1.7) is one of the enzymes of the respiratory process. It belongs to the group of oxidoreductase. Peroxidase contains heme (protoporphyrin IX). The enzyme causes oxidation of some organic compounds such as phenols, amines and some other heterocyclic compounds with hydrogen peroxide [4]

Donor- $\mathrm{H}_{2} \mathrm{O}_{2}=$ oxidized donor $+\mathrm{H}_{2} \mathrm{O}$

Unlike catalases, peroxidase does not cause oxidation of hydrogen peroxide and spirits. Under the action of catalase $\mathrm{H}_{2} \mathrm{O}_{2}$ is decomposed into molecular oxygen and water while peroxidase can restore $\mathrm{H}_{2} \mathrm{O}_{2}$.

The interaction of peroxidase with $\mathrm{H}_{2} \mathrm{O}_{2}$ forms intermediate compounds which have different spectral properties. Today there are known 4 types of such compounds. According to Chance the process is going on as follows:

$$
\begin{aligned}
& \text { - peroxidase } \mathrm{Fe}^{3+}+\mathrm{H}_{2} \mathrm{O} \text {--complex } 1 \\
& \text { - complex } 1+\mathrm{AH}_{2}-\text { complex II+AH } \\
& \text { - complex II }+\mathrm{AH}_{2}+\text {-peroxidase } \mathrm{F}^{3=}+\mathrm{AH}
\end{aligned}
$$

\section{Literature review}

Complex I is formed as soon as $\mathrm{H}_{2} \mathrm{O}_{2}$ is added. It is an unstable compound with green color which can be easily transformed into complex II. Complex II is formed from the excess amount of $\mathrm{H}_{2} \mathrm{O}_{2}$ and has red color. These compounds are not characterized by catalytic action. Their formation hinders the peroxidase action $[4,5]$.

Peroxidase protects a cell from the harmful action of $\mathrm{H}_{2} \mathrm{O}_{2}$ and actively participates in cell metabolism. It is mainly localized in mitochondria and chloroplast. Some researchers admit existence of peroxidase in ribosomes and nucleus. Peroxidase regulates the process of plant growth and development, because it is the part of the indoxylic enzyme system $[3,6]$.

Polifenol oxsidase (EC 1.10.3.1) contains copper, which has an influence on different o-phenols. The enzyme activates molecular oxygen and oxidizes dioxyphenol (sometimes even the monophenols) [7]. diphe- 
noloxidases catalyze two strong reactions of different mechanisms:

1) o-dioxyphenol oxidation into o-chinon (i.e. "catechinoloxidase activity);

2) monooxyphenol hydroxilization forming odioxyphenol (cresol action).

The enzyme is widely spread in plants. It is the result of the polyphenol oxidase action when a fruit and vegetable change color on air as soon as they are cut. The enzyme is easily solved in water. Therefore, it is not easy to define its localization in a cell. Supposedly, they occur in mitochondria and plastids, though some scientists have different viewpoints, therefore, the question of its localization requires investigation and specification [8]. Microelements influence the enzyme activity $[9,10]$.

\section{Aim and objectives of the study}

Aim - The effect of microelements on the activities of peroxidase in the eggplant leaves and fruit.

To achieve this aim, it was necessary to solve the following problems:

1. Microelements are necessary for normal processes of metabolism in the living bodies. They are related to vitamins, hormones, enzymes, therefore, play a significant role in growth and development of the body.

2. Microelements introduced to plants through fertilizers stimulate their growth and development, and increase the crop. However microelements have different action on different effect on one and the same plant in different phases of vegetation. Therefore, is it necessary to estimate the exact doses of microelements according to the soil type.

\section{Materials and Methods}

The object of the study was eggplant species "Dark" (solanum melongela L.), which is widespread in our conditions. Before sowing the eggplant seeds were treated in $0.02 \%$ - solutions of $\mathrm{ZnSO}_{4} . \mathrm{CuSO}_{4}, \mathrm{CoCl}_{2}$, $\mathrm{KMnO}_{4}, \mathrm{H}_{3} \mathrm{BO}_{3}$. The control seeds were processed in distilled water. After drying the seeds were sown on an experimental plot. Its biochemical analysis on the content of microelements was preliminarily carried out. The material (the leaves of the middle layer) for the analysis was taken at 12 o'clock of the day.

The activity of enzyme peroxidase was defined in the acetone preparation obtained from the raw material.

The acetone preparation of $20 \mathrm{mg}$ was placed in the test-tube and was added with $3.0 \mathrm{ml}$. M/ 15 phosphoric buffer (whose $\mathrm{PH}$ is equal to 6.0 ) $10 \mathrm{mg}$ pyrogallol (solution in $1.0 \mathrm{ml}$ water) and $1.0 \mathrm{ml} 1.0 \%-\mathrm{H}_{2} \mathrm{O}_{2}$. Reaction proceeded for 10 minutes. After that the solution was added with $5.0 \mathrm{ml}$ of ethyl alcohol for activation of the enzyme and then it was filtered. In the filtrate the optical density was defined by means of photoelectrometric colorimeter at $360 \mathrm{~nm}$.

The possible amount of enzyme polyphenol oxidase was deducted from the received number. For that the test-tube was placed according to the above described general scheme of reaction in conditions of introduction of $1.0 \mathrm{ml}$ water instead of $1 \%$ hydrogen oxide [1].

\section{Result of research}

The results of the analysis are given in Table 1, 2.

Table 1

Influence of microelements on the activity of peroxidase in eggplant leaves and fruit (\%)

\begin{tabular}{|l|l|l|l|l|l|l|}
\hline version & $\begin{array}{l}\text { phase of 4-5 } \\
\text { leaves appear- } \\
\text { ing }\end{array}$ & $\begin{array}{l}\text { phase of 6-7 } \\
\text { leaves appear- } \\
\text { ing }\end{array}$ & $\begin{array}{l}\text { phase of blos- } \\
\text { soming }\end{array}$ & $\begin{array}{l}\text { phase of fruit } \\
\text { appearing }\end{array}$ & $\begin{array}{l}\text { phase of ma- } \\
\text { ture fruit }\end{array}$ & $\begin{array}{l}\text { phase } \\
\text { technical rip- } \\
\text { ening of fruit }\end{array}$ \\
\hline Control & $7.6 \pm 0.01$ & $15.2 \pm 0.01$ & $15.2 \pm 0.01$ & $11.2 .2 \pm 0.01$ & $13.0 \pm 0.01$ & $5.0 \pm 0.01$ \\
\hline $\mathrm{H}_{3} \mathrm{BO}_{3}$ & $7.0 \pm 0.01$ & $13.6 \pm 0.01$ & $13.6 \pm 0.01$ & $37.0 \pm 0.01$ & $9.0 \pm 0 / 01$ & $11.2 \pm 0 / 01$ \\
\hline $\mathrm{ZnSO}_{4}$ & $7.4 \pm 0.01$ & $11.4 \pm 0.01$ & $11.4 \pm 0.01$ & $25.6 \pm 0.01$ & $11.2 \pm 0.01$ & $18.0 \pm 0.01$ \\
\hline $\mathrm{CuSO}_{4}$ & $3.0 \pm 0.01$ & $9.8 \pm 0.01$ & $9.8 \pm 0,01$ & $18.0 \pm 0.01$ & $13.3 \pm 0.01$ & $9.8 \pm 0.01$ \\
\hline $\mathrm{CoCL}_{2}$ & $6.0 \pm 0.01$ & $9.2 \pm 0.01$ & $9.2 \pm 0.01$ & $15.4 \pm 0.01$ & $5.8 \pm 0.01$ & $16.0 \pm 0.01$ \\
\hline $\mathrm{KMnO}_{4}$ & $17.8 \pm 0.01$ & $13.4 \pm 0.01$ & $13.4 \pm 0.01$ & $19.8 \pm 0.01$ & $7.8 \pm 0.01$ & $13.0 \pm 0.01$ \\
\hline
\end{tabular}

Table 2

Influence of microelements on the activity of polyphenol oxidase in eggplant leaves and fruit (\%)

\begin{tabular}{|l|l|l|l|l|l|l|}
\hline version & $\begin{array}{l}\text { phase of 4-5 } \\
\text { leaves appear- } \\
\text { ing }\end{array}$ & $\begin{array}{l}\text { phase of 6-7 } \\
\text { leaves appear- } \\
\text { ing }\end{array}$ & $\begin{array}{l}\text { phase of blos- } \\
\text { soming }\end{array}$ & $\begin{array}{l}\text { phase of fruit } \\
\text { appearing }\end{array}$ & $\begin{array}{l}\text { phase of ma- } \\
\text { ture fruit }\end{array}$ & $\begin{array}{l}\text { phase } \\
\text { technical rip- } \\
\text { ening of fruit }\end{array}$ \\
\hline Control & $15.4 \pm 0.01$ & $7.2 \pm 0.01$ & $7.0 \pm 0.01$ & $19 \pm 0.01$ & $0 \pm 0.01$ & $3.9 \pm 0.01$ \\
\hline $\mathrm{H}_{3} \mathrm{BO}_{3}$ & $20.6 \pm 0.01$ & $5.8 \pm 0.01$ & $12.6 \pm 0.01$ & $17 \pm 0.01$ & $0.7 \pm 0.01$ & $3.6 \pm 0.01$ \\
\hline $\mathrm{ZnSO}_{4}$ & $20.4 \pm 0.01$ & $11.0 \pm 0.01$ & $11.8 \pm 0.01$ & $13.4 \pm 0.01$ & $7.0 \pm 0.01$ & $3.0 \pm 0.01$ \\
\hline $\mathrm{CuSO}_{4}$ & $23.4 \pm 0.01$ & $29.8 \pm 0.01$ & $15.0 \pm 0.01$ & $13.0 \pm 0.01$ & $9.0 \pm 0.01$ & $11.2 \pm 0.01$ \\
\hline $\mathrm{CoCL}_{2}$ & $21.4 \pm 0.01$ & $35.0 \pm 0.01$ & $0 \pm 0.01$ & $0.8 \pm 0.01$ & $5.0 \pm 0.01$ & $18.0 \pm 0.01$ \\
\hline $\mathrm{KMnO}_{4}$ & $15.4 \pm 0.01$ & $3.6 \pm 0.01$ & $17 \pm 0.01$ & $11.4 \pm 0.01$ & $8.0 \pm 0.01$ & $5.4 \pm 0.01$ \\
\hline
\end{tabular}

In the phase of appearing 4-5 leaves the polyphenol oxidase activity in eggplant leaves is greater than that of peroxidase. In the next phase of vegetation of 6-7 leaves and in phase of blooming the peroxidase activity increases exceeding the polyphenol oxidase activity. In the phase of fruit bearing the polyphenol oxidase activity increases again and in the phase of technical ripening of fruit the activity of both enzymes decreases that is related 
to the age of the plant. In the phase of vegetation of 4-5 leaves the greatest increase of the polyphenol oxidase activity is observed first in the plants treated with copper and then in those treated with cobalt compared to the control version. The action of boron (20.6) and zinc (20.4) equally increases the enzyme activity.

In a case of boron the polyphenol oxidase activity is greater than that of peroxidase. The peroxidase activity is observed to be decreased and the polyphenol oxidase activity increased in comparison with the control version. And in phase of fruit bearing, on the contrary, the polyphenol oxidase activity is less decreased $(12.5 \%)$ and the peroxidase activity is 4-times increased. In the phase of technical ripening of fruit the polyphenol oxidase activity is greater than that of peroxidase. In the late phases of vegetation the peroxidase activity increases more than that of the polyphenol oxidase in the zinc version. As it was in case of the boron action, in those phases the peroxidase activity is greater than that of polyphenol oxidase (the latter decreases in comparison with the control group).

Copper treatment greatly increases the activity of polyphenol oxidase. Also, copper has a positive action on the peroxidase activity in the late phases of vegetation. With this respect a plant treated with copper significantly differs from the control group.

Cobalt increases the polyphenol oxidase activity in the phase of vegetation of 6-7 leaves while the activity of the enzyme is zero in the phase of blooming. In cobalt version the activity of polyphenol oxidase is greatest among the other versions.

Manganum effect on the activity of the enzymes under study is revealed in the later phase. The peroxidase activity is more increased.

In an immature fruit of eggplant the polyphenol oxidase activity is less than that of peroxidase. In the boron version the polyphenol oxidase activity is decreased (0.7), and peroxidase activity is also reduced.

The zinc and copper treatment increases polyphenol oxidase activity in eggplants. Unlike the other microelements in manganum version the activity of both enzymes is similar.

\section{Discussion}

Microelements are required by living organisms for the normal processes of metabolism. They are connected with the formation of vitamins, hormones, and ferments. Therefore, they play a very important role in the growth and development of organisms;

The provision of microelements for plants in the form of micro fertilizers improves their growth and development, increases yields. However, microelements affect differently various species of plants. More to the point, one and the same microelement has a varied effect on one and the same plant in the different stages of vegetation. Because of that, it is necessary to determine the exact ratio of microelements essential for plants, according to the types of soil. Due to the results gained from our experiment, an optimal ratio of microelements under study is $0,02 \%$ solution of salts.

Microelements can be supplied for plants when the quantity of theirs in the soil does not exceed a certain point, for example $\mathrm{Mn}-40,0 \mathrm{Mo}-0,20, \mathrm{Co}-1,5 \mathrm{Zn}-$ $0,3, \quad B-0,5 \mathrm{mg} / \mathrm{kg}$., and etc. Because of that, it is essential to conduct a preliminary study of the soil.

For plants to be supplied with micro fertilizers, it is more effective to treat seeds in a number of ways before sowing. Because that increases maximum intake of microelements; a plant embryo starts growing earlier, metabolic processes activate, the influence of microelements spread on the new cells formed through the division of cells in an early embryo. It is difficult to equally distribute microelements in a large area, because one hectare requires $3-5 \mathrm{~kg}$ of fertilizers. That's why it is convenient for farmers to soak seeds prior sowing in concrete water and salt solution together with the concentration referred to for 24 hours in specially equipped baths. After drying, seeds should be planted.

In regions, where the soil lacks the crop capacity, it is advisable for farmers to focus on the greenhouse cultivation of water cultures, which is of actuality in western countries (in the Czech Republic - tomato growing). Due to the experiment of ours, the impact of microelements in water cultures is more effective.

The influence of microelements on the increase of the crop capacity of vegetable cultures is rather important.

\section{Conclusions}

1. The activity of enzymes varies in different phases of vegetation of the plant under study. It can be explained by the fact that eggplant bears technically and physiologically ripe fruit together with crude fruit and buds and blossoms. In both versions (the controlled one and the one with microelements) with the increase of the peroxidase activity the polyphenol oxidase activity decreases.

2. In comparison to the control versions in the phase of vegetation of 4-5 leaves the polyphenol oxidase activity is greatest under the action of copper, than comes cobalt. While boron and zinc action on the enzyme activity is similar. Under the action of boron the polyphenol oxidase activity is especially increased in the phase of appearing 4-5 leaves, while in later phases it is decreased and the peroxidase activity changes accordingly).

3. At pre-sowing treatment of seeds with zinc the peroxidase activity in leaves (early phase of vegetation) and fruit decreases, while at vegetation of the fruit it reaches its maximum.

4. Under the action of copper and cobalt the peroxidase activity increases in leaves (late phase) and fruit.

5. Manganese has lesser effect on the activity of polyphenol oxidase in the earlier phase than in the later phase. In eggplant fruit the activity of polyphenol oxidase increases.

\section{References}

1. Tkemaladze, G. Enzimologia Practicuml [Text] / G. Tkemaladze, G. Kvesitadze. - Tbilisi, 2000 - 298 p.

2. Shkolnik, M. I. Mikroelementy v zhizni rastenii [Text] / M. I. Shkolnik. - Leningrad, 1974. - 323 p.

3. Rubin, B. A. Fiziologiia i biokhimiia dykhaniia rastenii [Text] / B. A. Rubin, M. E. Ladygina. - Moscow, 1974. - 512 p.

4. Yakushkina, N. I. Fiziologia rastenii [Text] / N. I. Yakushkina, E. Yu. Bakhtenko. - Moscow, 2005. - 463 p. 
5. Bitiuzkii, N. P. Mikroelementi i rasteniia [Text] / N. P. Bitiuzkii. - Moscow, 1999. -232 p.

6. Goodwin, T. Vvedenie v biokhimii rastenii. Vol. 1 [Text] / T. Goodwin, E. Mercer. - Moscow, 1986. -392 p.

7. Libbert, E. Fiziologiia rastenii [Text] / E. Libbert. - Moscow, 1976. - 580 p.

8. Mangaladze, N. The effect of Mn on catalase activity in vegetable plants [Text] / N. Mangaladze // The First SDSUGeorgia STEM WORKSHOP on Nanotechnolog and Environmental Sciences. - Tbilisi, 2015. - P. 59-60.

9. Mangaladze, N. The influence of Co on catalase activity in vegetable plants [Text] / N. Mangaladze, N. Kiladze // Bulletin of the Georgian National Academy of Sciences. - 2014. - Vol. 8, Issue 1. - P. 76-80.

10. Mangaladze, $\mathrm{N}$. The effect of microelements on the activities of peroxidase and polyphenol oxidase in tomato leaves and fruit [Text] / N. Mangaladze // Bulletin of the Georgian National Academy of Sciences. - 2015. - Vol. 9, Issue 3. - P. $139-142$.

Presented by Georgian National Academy Member Nugzar Alexidze Дата надходження рукопису 30.11.2017

Nino Mangaladze, Associate Professor, Department of Biology, Kutaisi Akaki Tsereteli State University, Tamar Mephe str., 59, Kutaisi, Georgia, 4600

УДК 636.028/.09:616.15:591.1

DOI: $10.15587 / 2519-8025.2017 .118786$

\title{
ГЕМАТОЛОГІЧНІ ПОКАЗНИКИ ЩУРІВ ЗА ШТУЧНОГО ГІПОБІОЗУ
}

\author{
(С) А. О. Уманська, Д. О. Мельничук, Л. Г. Калачнюк
}

На сьогоднішній день є досить актуальними для медицини дослідження способів загального обезболювання, консервації крові тощзо на основі введення організму у стан штучного гіпобіозу. Для детального дослідження даного стану, насамперед, необхідно детальніше дослідити гематологічні показники у стані штучного гіпобіозу та через 24 год після виходу з нього. Було показано значне підвищення еритроцитів і тромбоцитів, однак зменшення вмісту лейкоичитів

Ключові слова: гіпобіоз, гіперкапнія, гіпоксія, еритроцит, лімфоцит, тромбоцит, кров, иури, гематологія, лейкоиит

\section{1. Вступ}

У сучасному світі актуальною проблемою біології та практичної медицини залишається дослідження адаптації тварин до низьких температур довкілля [1]. Штучна гіпотермія широко використовується в медичній практиці з метою лікування та реабілітації після різноманітних захворювань, оперативних втручань тощо $[1,2]$. Це пов'язано зі значним зниженням обміну речовин і використання кисню при пониженій температурі та подальшим відновленням фізіологічних функцій після нормалізації температури.

Стан штучної гіпотермії можна створити із використанням гіпокси-гіперкапнічних газових середовищ. За цих умов тварини входять в стан штучного гіпобіозу при зниженні температури тіла до $14-23{ }^{\circ} \mathrm{C}[3,4]$. Одним 3 таких способів $є$ методика за Бахметьєва-Джайя-Анжуса [4]. Формування штучного гіпобіотичного стану веде до гіпометаболізму, що супроводжується зниженням енергозабезпечення теплокровного організму [5, 6]. На сьогоднішній день досліджено досить багато біохімічних та фізіологічних показників стану організму за штучного гіпобіозу.

\section{2. Літературний огляд}

Терміном «гіпобіоз» (грецьк. һуро - під, внизу та bios - життя) характеризують стан природного (різного глибини) пригнічення життєдіяльності організму, в тому числі і стан зимової чи літньої сплячки тварин, або зимового заціпеніння. Він був запропонований Б. Монтересо у 1934 р. [7].

Введення гомойотермних організмів в стан штучного гіпобіозу, з метою досягнення повної нечутливості перед хірургічним втручанням, займалися ще в минулому столітті [8]. Для введення лабораторних тварин в стан штучного гіпобіозу використовували метод «закритої судини», запропонований Бахметьєвим, який полягає в їх охолоджені в умовах поступово зростаючої в процесі дихання гіпоксії і гіперкапнії [9]. В подальшому П. Бахметьєв, Д. Джай та Р. Анжус при проведенні хірургічних втручань на дрібних тваринах для їх охолодження до $18-20{ }^{\circ} \mathrm{C}$ використовували метод «закритої судини» [10].

Експерименти, які були проведені Е. В. Майстрах свідчать, що пригнічення життєдіяльності можна досягнути одночасним охолодженням та вдиханням газової суміші з високою концентрацією кисню (до 90-95 \%) з додаванням вуглекислого газу, яка має збуджуючу дію на дихальний центр. Штучне дихання комбінувалось зі штучним кровообігом і введенням лікарських речовин [11].

У подальшому для створення штучного гіпометаболічного стану використовували окремими очищені фракції і проміжні продукти метаболізму, виділені з мозку, тонкого кишечнику, крові та печінки [12]. При введенні таких ендогенних речовин 3 тканин тварин, що впадають у природній гіпобіоз у кров білих мишей спостерігалося інгібування секреції гормонів передньою і задньою частками гіпофізу, 